\title{
Working
}

Paper 


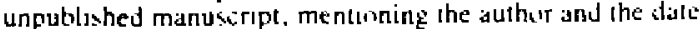
of is suance by the Intematurinal Mronelasy Fund The vewh expressed are those ot the duthor Jnd jo noy necessarbly represent those wi thi Fund

\section{Capital Mobility and Monetary Policy in Colombia}

Prepared by Robert Rennhack and Guillermo Mondino $1 /$

Authorized for Distribution by Miguel Bonangelino

August 9,1988

\section{Abstract}

This paper estimates a model of financial markets in Colombia to examlne: 1) the authorities' control over domestic interest rates and the money stock; and 2) the effects of the crawling peg exchange rate policy on exchange rate expectations and domestic lnterest rates. The authorities appeared to possess some control over the money stock in the short run, mostly because of the existence of capital controls, but most of this control was eroded once asset denands adjust to their desired banks. The expected rate of depreciation is not closely linked to the crawling peg.

MASEE FILES

Fin $:-130$

แi]

JEL Classification Number:

431

1/ Guillermo Mondino, a graduate student at Yale University, worked on this project as a summer intern. This paper benefited f rom the coments of Miguel Bonangelina, Hernando Gomez, Lorenzo Perez, and Frits van Beek. 
Summary

I. Introduction

II. The Structural Model of Colombian Financial Markets

III. Empirical Results

1. Sterilization policy

2. The crawling peg and exchange rate expectations

3. Asset demands

4. The degree of capital mobility

Tables

1. Banco de La Republica Domestic Credit Policy

2. Banco de la Republica Exchange Rate Policy

3. Random Walk Test of the Exchange Rate (1977:1 to 1985:4)

4. Real Demand for Net Foreign Assets (1976:4 to 1985:3)

5. Real Demand for M1 (1975:2 to 1984:2)

6. The Degree of Capital Mobility

\section{Appendices}

I. Data Source

I. Derivation of the Monetary Policy Measures

\section{Charts}

1. Domestic and Foreign Incerest Rates

2. Net Foreign Assets of Private Sector

3. Actual Depreciation

4. Actual Versus Expected Rate of Depreciation

Bibliography

(C) International Monetary Fund. Not for Redistribution 


\section{Summary}

Thls paper develops a model of financlal markets In Colombla during 1977-85 to examline the authorlties' control over domestlc lnterest rates and the money stock as well as the effects of the crawling peg on exchange rate expectatlons and domestlc interest rates. The paper presents estlmated equations for the demand for money and net forelgn assets using a regresslon to the amount of private capltal inflow (outflow) for each unlt of contraction (expansion) of net domestlc credit of the Banco de la Republica.

The results suggest that the authorltles possessed some control over the money stock in the short run, princlpally through the use of capltal controls, but most of thls control was eroded once asset demands adjusted to their deslred levels. There was evidence of Imperfect substitution hetween domestlc and forelgn assets, provlding open-market operatlons with some long-term control over the stock of money. The expected rate of depreciat Ion was not closely 1 Inked to the crawling peg, implylng that an acceleration In the rate of crawl would not necessarlly have driven up domestlc interest rates. 
This page intentionally left blank

CInternational Monetary Fund. Not for Redistribution 


\section{Introduction}

An important policy question for a small open economy is the authorities" degree of control over domestic interest rates and the money stock. As is well known for small open economies with fixed exchange rates, private capital flows may offset changes in the stock of domestic credit, and impair the authorities' ability to control the stock of money. The behavior of capital flows also influences the impact of foreign monetary conditions on domestic interest rates, with the domestic interest rate equaling the foreign interest rate plus the expected rate of depreciation in the case of perfectly mobile capital. This relationship anong interest rates and the exchange rate is particularly important in a country, such as Colombia, that follows a crawling peg exchange rate policy. An acceleration of the rate of crawl may lead to a faster expected rate of depreciation, putting upward pressures on domestic interest rates or creating an incentive for capital outflows.

In this paper, we estimate the degree of private capital mobility in Colombia to investigate the effectiveness of domestic credit policy as an instrument of monetary control and the possible monetary implica$t$ ions of Colombia's exchange rate regime. There is no strong evidence of a high degree of capital mobility. Between 1977 and 1985, there were significant differences between the domestic interest rate, as measured by the nominal return on 90-day certificates of deposit, and the foreign rate of return, which is defined as the U.S. treasury bill rate plus the expected rate of depreciation of the peso (Chart 1). Before 1980, the foreign rate of return fluctuated at levels lower than the domestic interest rate, and then, after moving above the domestic rate in 1981 , it rose sharply in 1983 and 1984 largely because of an increase in the expected rate of depreciation (as estimated for this paper). It peaked in early 1985 when the authorities began to accelerate the pace of depreciation of the peso; by the end of 1985, the peso had been depreciated by over 50 percent in nominal terms against the U.S. dollar. The domestic interest rate was fixed prior to 1980 , but after being freed in 1980 , it remained very stable between 1981 and 1985 in spite of the large movements in the foreign rate of return. While the behavior of interest rates is consistent with the presence of capital controls in Colombia, movements of capital were sizable in this period. $1 /$ From the beginning of 1977 to the end of 1980, net foreign assets held by the private sector fell from close to zero to about minus US\$1 billion, an annual average net capital inflow of about US\$250 million (Chart 2 ). From the end of 1980 to the end of 1994, private net foreign assets rose from minus US\$1 billion to about US\$800 million, a cumulative outflow of approximately US\$1.8 billion during a period in which Colombia lost almost US\$4 billion of its net official international reserves.

1/ The export of capital by private residents is prohibited in most cases, and foreign borrowing by the private sector is subject to certain conditions. See International Monetary Fund, Annual Report on Exchange Arrangements and Exchange Restrictions, for Eurther details. 
There are few econometric studies of the independence of monetary policy in Colombia, and there is Little conclusive evidence. Fernandez and Candelo (1983) estimate a structural model similar to the one employed in this paper with mixed econometric results. Kamas (1985) develops a small reduced form macro-econometric model to examine the impact of foreign shocks on the Colombian economy. Among her results, she finds that the monetary authorities have some control over the money supply in the short run, with an estimate of -0.43 for the short-run offset coefficient, while the long-run offset coefficient is -0.83 , implying a lower degree of control. In her model, however, the offset occurs through the current account, while the capital account offset is negligible. Montes and Candelo (1982) estimate a small monetary approach model that incorporates the presence of nontraded goods and a crawling peg, and find that an expansion of net domestic credit of the Banco de la Republica would quickly lead to an equivalent loss of net international reserves. Edwards (1985) and Edwards and Kahn (1985) use a model that allows for the presence of capital controls to test for the relative importance of foreign versus domestic monetary factors on the domestic interest rate; the results suggest that uncovered interest parity will hold about one year after a shock to the foreign interest rates or the expected rate of depreciation.

In this paper, we estimate a small structural model of Colombian financial markets similar to the one developed for Mexico by Cumby and obstfeld (1983). 1/ This model allows domestic and foreign returns to differ because of risk aversion as well as capital controls, and it is used to calculate an offset coefficient, which measures the flow of private capital in response to a one peso change in the stock of domestic credit. By estimating a structural model, as opposed to a reduced form model, we are able to correct for any bias introduced by possible systematic sterilization of movements in net international reserves. The model also enables us to examine the relationship between Colombia's crawling peg exchange rate policy and exchange rate expectations, domestic interest rates, and capital flows. As a short-run model of financial markets, it treats the domestic price level and the current account as exogenous, and thus it tends to understate the size of the offset coefficient.

The results suggest that the capital account offset to domestic credit policy is low in the short run, but the control over the money stock is reduced substantially over time as the stock of net foreign assets adjusts to its desired level. Nonetheless, it appears that capital controls make the adjustment in the stock of net foreign assets relatively slow, allowing a degree of monetary control over a period of several years. The evidence of imperfect capital mobility implies that

1/ Another example of a structural approach is Herring and Marston $(1 \overline{9} 77)$. Examples of the reduced form approach include Kouri and Porter (1974), Porter (1972), Kamas $(1985,1986)$, and Conolly and da Siviera (1979). 
CHART 1

COLOMBIA

DOMESTIC AND FOREIGN INTEREST RATES

(In percent per quorter)

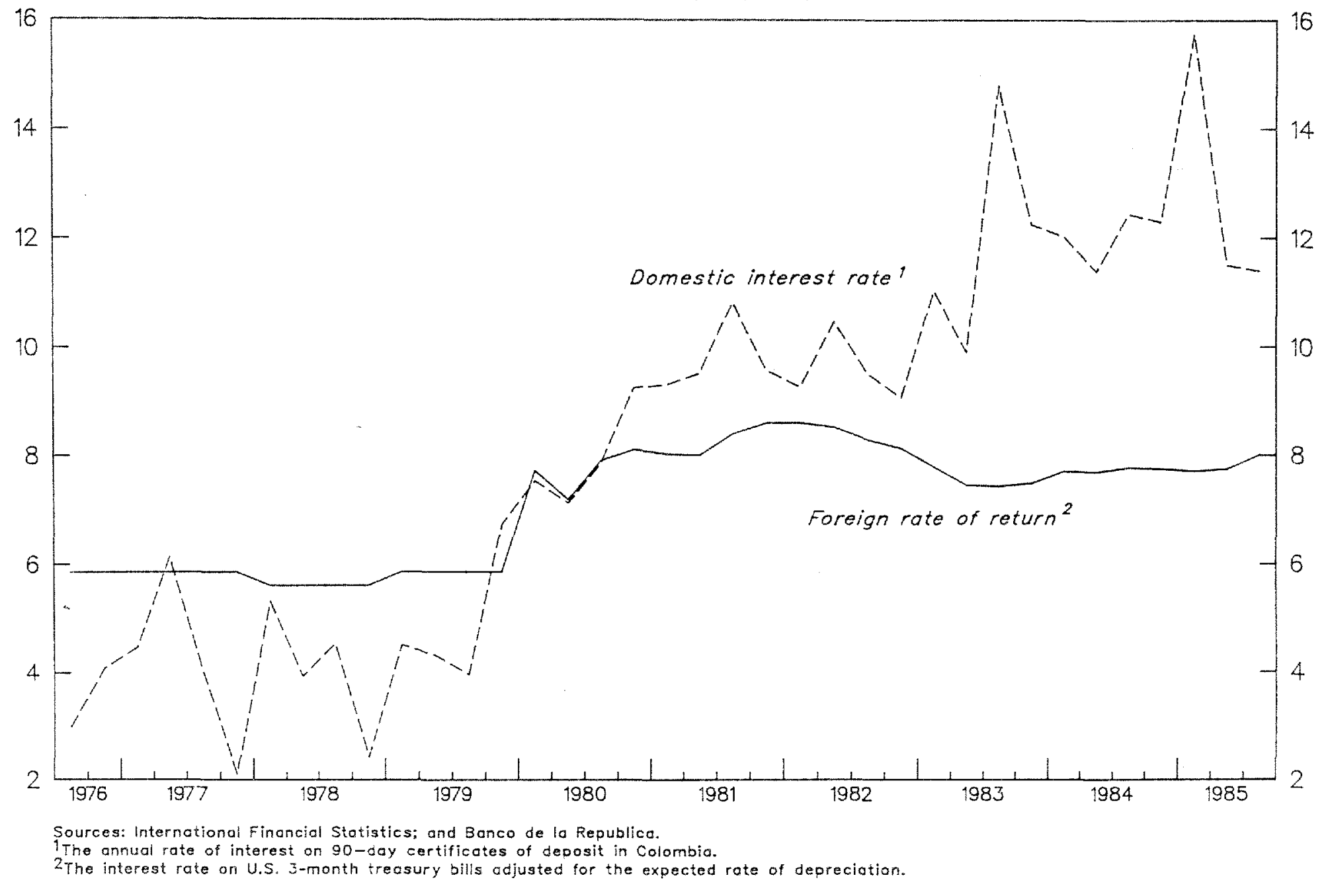


CHART 2

COLOMBIA

NET FOREIGN ASSETS OF PRIVATE SECTOR ${ }^{1}$

(in billions of U.S. doilars)

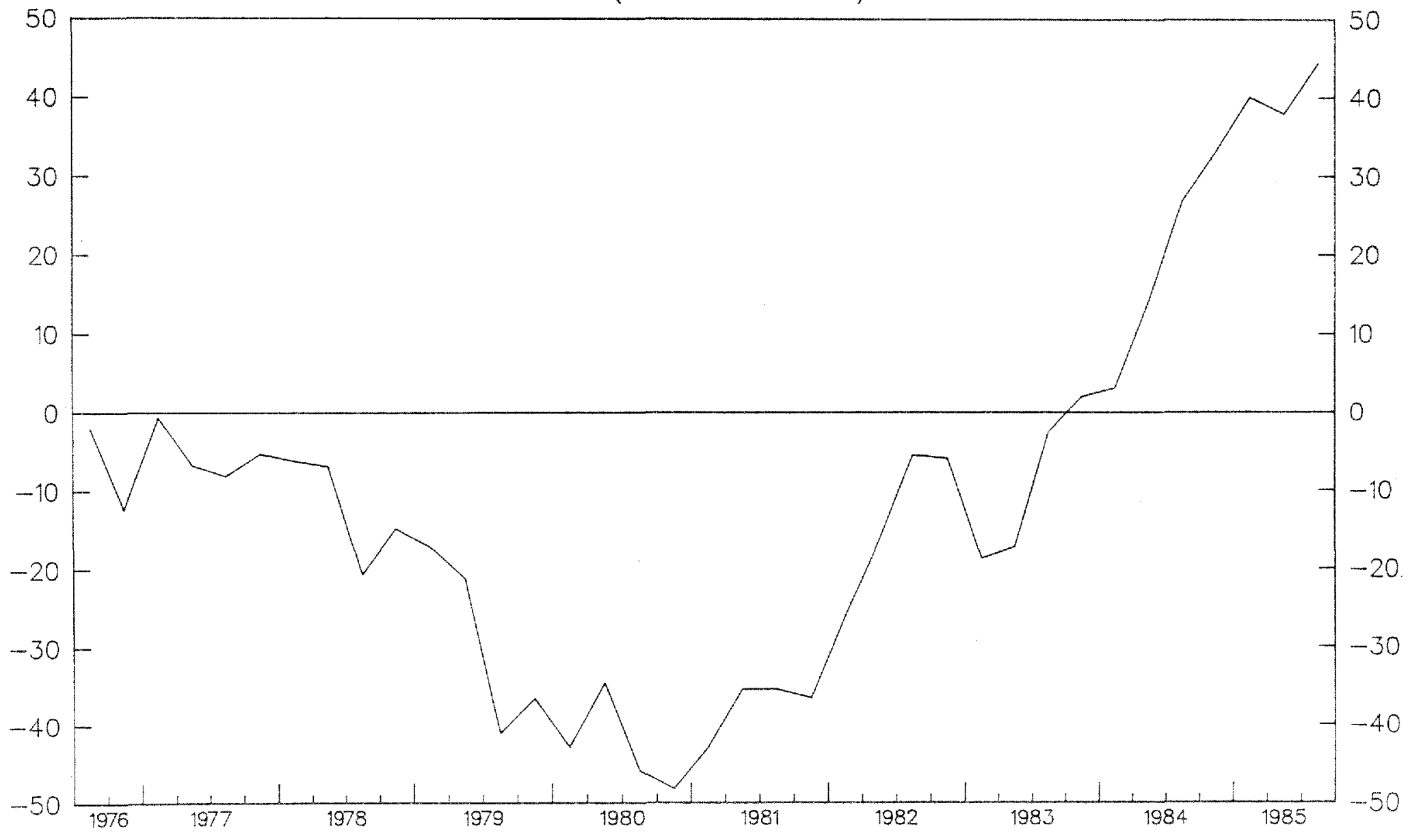

Sources: U.S. Federal Reserve Monthly Bulletin; and Banco de la Republica.

Measured by stock of deposits of Colomblans in U.S. banking system minus the deposits of the Bonco de la Republica in U.S. bonks and mimus foreign liabilities of Colombion commercial banks and finoncial corporations. 
an increase in the rate of crawi, if it translates into a faster expected rate of depreciation, would raise the level of domestic interest rates by a small amount in the short run. The model suggests, however, that domestic interest rates rige by about two-thirds of an increase in the expected rate of depreciation, once the stock of net foreign assets has adjusted to its desired level. We also find some evidence that a faster expected rate of depreciation lowers the demand for money, which would weaken the link between domestic and foreign interest rates even with a high degree of capiral mobility.

The organization of the paper is as follows: Section II presents the structural model of financial markets and discusses the derivation of the offset coefficient. Section III gives the empirical results. Section IV presents concluding remarks.

\section{The Structural Model of Colombian Financial Markets}

The decision of residents of Colombia to invest abroad, rather than at home, is based on portfolio choices, which take into account the returns on domestic and foreign assets, the riskiness of each asset, and investor's wealth. By altering the return on domestic assets, a change in the stock of net domestic credit of the central bank provides an incentive for investors to reallocate their wealth among domestic and foreign assets. For example, an expansion of domestic credit lowers the domestic interest rate, and with no change in the return or risk on foreign assets, investors will shift more of their wealth toward foreign assets, creating an outflow of capital. If domestic and foreign assets are regarded as perfect substitutes and asset stocks adjust instantly to desired levels, the credit expansion results in an equivalent outflow of capical, and the domestic money stock remains unchanged. Thus, under conditions of perfect capital mobility, the authorities control the level of domestic credit but not the money stock; moreover, a faster unanticipated tate of crawl may raise the expected rate of depreciation and lead to an increase in domestic interest rates.

One summary measure of the degree of mobility of private capital is the offset coefficient, which gives the amount of capital outflow (inflow) per peso of expansion (contraction) of domestic credit. The coefficient ranges from zero to minus one, and its magnitude depends mainly on the elasticity of the demands for money and net foreign assets with respect to the domestic interest rate. If domestic and foreign assets are close substitutes, the demand for net foreign assets is very sensitive to changes in the domestic interest rate, and the offset coefficient is close to minus one, indicating a high degree of capital mobility and a low degree of control over the money stock. If the interest elasticity of the demand for money is very low, a larger change in the domestic interest rate is needed to maintain equilibrium in the domestic money market after a change in the stock of domestic credit. This response also contributes to an offset coefficient closer co minus one. With the opposite pattern of interest elasticities--insensitive 
demand for net foreign assezs and sensicive money demand--the offset coefficient is close to zero, implying a high degree of monetary control and a low degree of capital mobility. The offset coefficient is also determined to a lesser extent by other parameters of the model, such as the money multiplier and the share of wealth allocated to net foreign assets.

Capital mobility depends on the speed of adjustment of actual asset holdings to their desired levels as well as on the substitutability of domestic and foreign assets. An independent monetary policy is possible if these two types of assets are imperfect substitutes or capital controls prevent asset holdings from responding quickly to changes in rates of return, risk or wealth. Because of the presence of capital controls in Colombia, our analysis distinguishes between an offset coefficient in the short run--before the stock of net foreign assets adjusts to its derived level--and one in the long run--once asset holdings have ad justed completely.

The formal model assumes that private investors allocate their wealth among three assets: domestic money, interest bearing local currency debt of the Government and the Banco de la Republica, and net. foreign assets. The demand for each asser in real terms is assumed co depend on the nominal domestic interest rate, the nominal foreign rate of return, domestic real income, and domestic real wealth. These private asset demands and the definition of wealth are presented in equations (1) through (4).

(1)
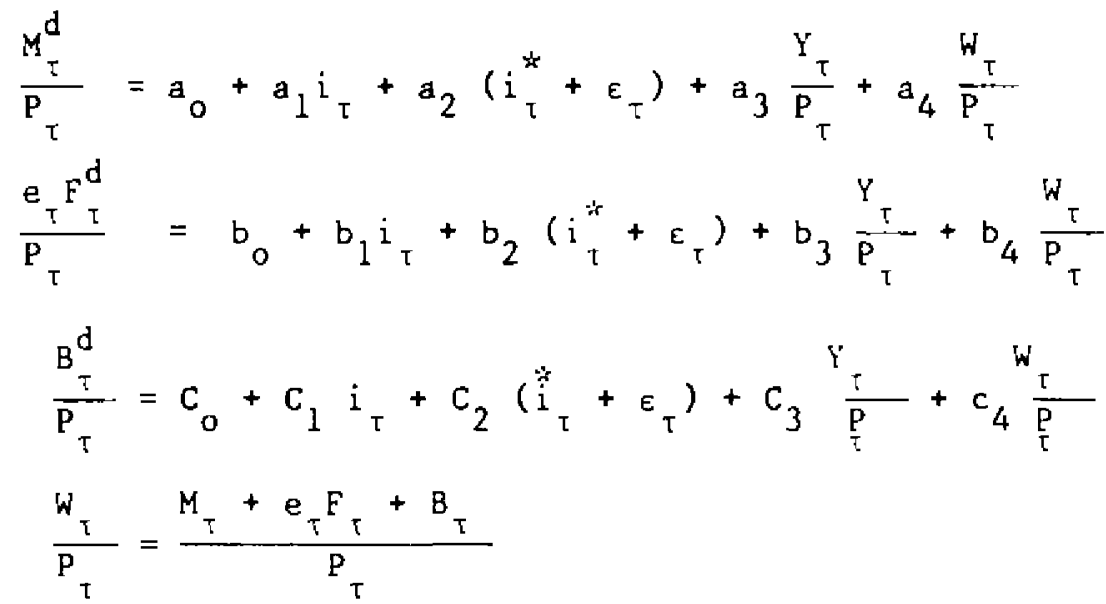

where $M$ is domestic money narrowly defined, $B$ is the domestic debt of the public sector, $F$ is net foreign assets in terms of U.S. dollars, W is domestic wealth, $e$ is the exchange rate of the peso in terms of pesos per U.S. dollar, $p$ is the domestic price level, i is the domestic interest rate, $i^{*}$ is the foreign interesc race, $\varepsilon$ is the expected rate of depreciation, and $Y$ is nominal gross domestic product. $1 /$

1/ Data sources and definitions are summarized in Appendix I. 
In this model, we assume that there is no foreign demand for pesodenominated assets and that the foreign interest rate is exogenous. Initially, we consider the expected rate of depreciation exogenous and then point out the implications of endogenous exchange rate expectations. Because this is a short-run model of financial markets, we treat GDP and the price level as exogenous. Money demand responds negatively to increases in both rates of return and both $a_{1}$ and $a_{2}$ are less than zero. In the case of demand for the two interest-bearing assets, we adopt the assumption of gross substitution, which means that each asset reacts positively to increases in its own rate of return and negatively to increases in the other rate of recurn. Thus $c_{1}$ and $b_{2}$ are positive, while $b_{1}$ and $c_{2}$ are negative. An increase in output and wealth raises the demand for all assets, and $a_{3}, a_{4}, b_{3}, b_{4}, c_{3}$, and $c_{4}$ are all greater than zero. The definicion of wealth implies that $a_{4}+b_{4}+$ $c_{4}=1$, that is, asset shares must sum to 1 . Moreover, $a_{1}+b_{1}+c_{1}=0$ and $a_{2}+b_{2}+c_{2}=0$; a portfolio reallocation due to changes in rates of return involves a constant level of wealth and increases in holdings of one asset must come at the expense of holdings of the other assets.

It is also necessary to specify the supply side of asset markets. By definition, the stock of narrow money equals the money multiplier times the monetary base, which is the stock of net domestic credit and net international reserves of the Banco de la Republica:

$$
\text { (5) } M_{\tau}^{3}=q_{T}\left(D C{ }_{\tau}+e_{\tau} R_{\tau}\right)
$$

where $q$ is the money multiplier, $D \mathcal{C}$ is the stock of net domestic credit of the Banco de la Republica, and $R$ is the stock of net international reserves of the Banco de la Republica in terms of U.S. dollars. Net foreign assets of the private sector move according to the difference between the current account balance, including direct foreign investment in Colombia and public capital flows, and the change in net international reserves of the Banco de la Republica:

(6) $\quad d F_{\tau}=\mathrm{CA}_{\tau}-\mathrm{dR}_{\tau}$

where CA is the current account balance as defined above. In this model, the current account is assumed to be exogenous, and therefore. changes in net foreign assets must translate into movements in net international reserves and the monetary base.

The definition of wealth means that there are only two independent asset demands, and for the purpose of this analysis, we focus on the demand for money and the demand for net foreign assets. These two equations allow us to solve for the model's two endogenous variables: the domestic interest rate and the stock of net foreign assets. To simplify the exposition of the offset coefficient, we assume that the 
wealth effects on money demand are zero, i.e., $a_{4}=0$. By totally differentiating Equations (1) and (2) and setting asset demands equal to asset supplies, the six equations reduce to two simultareous equations:

(7)

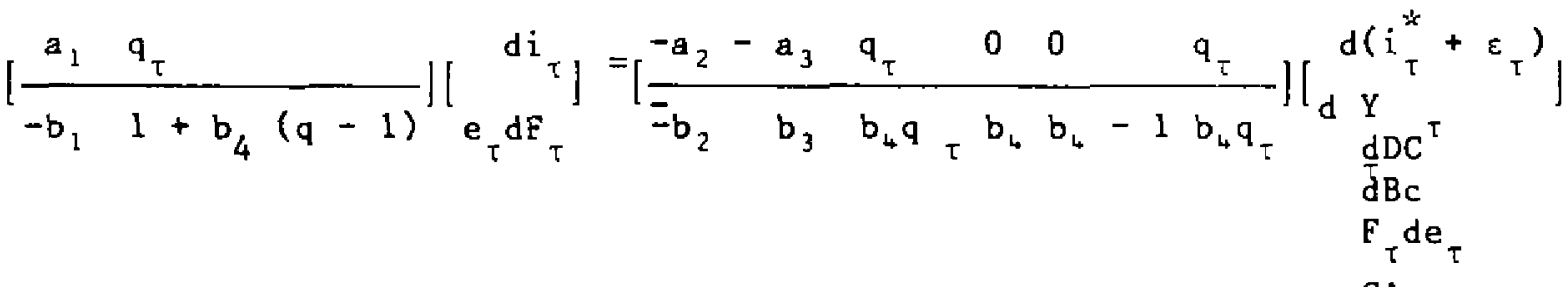
CAteT

The private capital outflow due to an expansion of net domestic credit equals:

$$
-\frac{e_{\tau} d F_{\tau}}{d D C_{\tau}}=-\frac{b_{1} q_{\tau}}{a_{1}\left(1+b_{4}(q-1)\right)+b_{1} q_{\tau}}-\frac{a_{1} b_{4} q_{\tau}}{a_{1}\left(1+b_{4}(q-1)\right)+b_{1} q_{\tau}}
$$

The first expression on the right hand side represents the impact of the change in the domestic interest rate on the demand for net foreign assets. As domestic and foreign assets become close substitutes, $b_{1}$ approaches minus infinity, and the value of this term approaches minus one. The second term measures the impact of the change in the level of wealth on the demand for net foreign assets. In the case of perfect capital mobility, this term equals zero. It is useful to distinguish between two types of domestic credit policies: (1) a helicopter drop, a change in net domestic credit with no offsetting change in domestic public debt; and (2) an open market operation, which involves a swap of domestic credit and domestic public debt that keeps the level of private wealth unchanged. The offset coefficient for a helicopter drop includes both the interest rate and wealth effects in Equation (8), while for an open market operation, it equals just the interest rate effect. Thus, the offset coefficient is closer to minus one in the case of a helicopter drop.

Another measure of the degree of capital mobility is the response of the domestic interest rate to a change in the foreign rate of return. In this model, this relationship equals:

(9)

$$
\frac{d i_{\tau}}{d\left(i_{\tau}^{i}+\varepsilon_{\tau}\right)}=\frac{-a_{2}\left(1+b_{4}(q-1)\right)-b_{2} q_{\tau}}{a_{1}\left(1+b_{4}(q-1)\right)+b_{1} q_{\tau}}
$$


If the foreign rate of return has no impact on money demand, $a_{2}=0$, this expression yields the same information as the offset coefficient in the case of open market operations. Thus a high interest sensitivity of money demand with respect to the foreign rate of return weakens the link between domestic and foreign interest rates even with a substantial capital account offset. For example, an increase in the expected rate of depreciation raises the demand for net foreign assets, putting upward pressure on the domestic interest rate, but if $a_{2}$ is less than zero, the higher expected depreciation also lowers money demand, requiring a lower domestic interest rate. In this situation, the additional holdings of net foreign assets in the short run come from investors' stocks of money as well as domestic public debt. This result is plausible in a country like Colombia, where secondary markets for public debt instruments are relatively thin.

The analysis so far assumes that exchange rate expectations are exogenous. Nonetheless, it is possible that changes in net international reserves alter the expected rate of depreciation. For example, an expansion of domestic credit that resulted in a loss of reserves may also produce a faster expected rate of depreciation, especially if the authorities tied the rate of crawl to movements of net international reserves. To illustrate the impact of endogenous exchange rate expectations, we assume that the authorities adjust the peso according to a systematic rule and that private investors use this rule to forecast the exchange rate. Thus, we express the expected rate of depreciation as:

$$
\left.\varepsilon_{\tau}=\frac{d e_{\tau}}{e_{\tau}}=d_{1} \frac{d R_{\tau}}{R_{\tau}}+d_{2} \frac{\left(d P_{\tau}\right.}{P_{\tau}}-\frac{d P_{\tau}^{*}}{P_{\tau}^{*}}\right)
$$

where $\mathrm{P}^{*}$ is the foreign price level. The underlying rule states that the authorities move the nominal exchange rate in $l$ ine with the inflation differential, and adjust the real exchange rate to compensate for reserve flows. After substituting (11) into the system of Equation (7), the offset coefficient equals:

$$
-\frac{e_{\tau} d F{ }_{\tau}}{d D C}=-\frac{\left(a_{1} b_{4} q_{\tau}+b_{1} q_{\tau}\right)}{a_{1}\left(1+b_{4}(q-1)+b_{2} d_{1}\right)+b_{1}\left(q_{\tau}-a_{2} d_{1}\right)}
$$

This expression is larger in absolute value than the offset coefficient with exogenous expectations given by Equation 8 . An expansion of domestic credit leads to a larget capital outflow because the effect of the lower domestic interest rate is now accompanied by a higher expected rate of depreciation. 


\section{Empirical Results}

Prior to discussing the estimates of the asset demand equations, we examine the domestic credit and exchange rate policies of the authorities. During periods of sharp increases in coffee exports, the Colombian authorities have attempted to sterilize the monetary impact of the large accumulation of net international reserves by slowing the growth of net domestic credit and lowering the money multiplier. This policy introduces an inverse relationship between private capital flows and changes in net domestic credit, even if private capital is relatively immobile. This means that the levels of net domestic credit and private net foreign asgets are determined simultaneously. One must account for this sterilization bias when estimating the offset coefficient.

Since 1967, Colombia has been following a crawling peg exchange rate policy aimed at promoting the growth of nontraditional exports and maintaining equilibrium in the overall balance of payments. If the rule governing the rate of crawl were systematic, it would be possible for private investors to use this information to forecast future values of the exchange rate, and an equation that explained the rate of crawl could provide estimates of the expected rate of depreciation. As discussed previously, any systematic connection between exchange rate expectations and reserve flows would have implications for the size of the offset coefficient.

\section{Sterilization policy}

To look at the degree of sterilization, we postulate that the authorities direct domestic credit policy toward achieving their objectives for growth in real output, the rate of domestic inflation, and the change in net official international reserves. Also, because of the thinness of capital markets in Colombia, net domestic credit must be used to finance at least part of the public sector deficit. We can express this policy rule as:

$$
\frac{D C_{\tau}}{P_{\tau}}-\frac{D C_{\tau-1}}{P_{\tau-1}}=f_{0}+f_{1} \hat{Y}_{t}+f_{2} \hat{P}_{\tau}+f_{3}\left(e_{\tau} R_{\tau}-e_{t-1} R_{\tau-1}\right)+f_{4} D_{5}
$$

where " denotes percentage change and $D_{5}$ is the fiscal deficit. According to this rule the authorities view faster growth of real output as an indication of stronger growth of real money demand, and they try to accommodate at least part of this additional demand through an expansion of credit. In addition, domestic credit policy is also used to influence the rate of inflation. The sterilization coefficient is given by $\mathrm{f}_{3}$. If the desired change in the monetary base is independent of the movements in reserves, $\mathrm{f}_{3}=-1$ and the authorities react to all reserve fluctuations with exactly offsetting changes in net domestic credit. If 
the authorities want to reduce the size of a balance of payments surplus, they will only partially sterilize the change in reserves, and $\mathrm{f}_{3}>-1$. By the same token, if they want to diminish a payments deficit, the observed sterilization coefficient will be less than minus one. Finally, at least part of the fiscal deficit is financed through an expansion of domestic credit. Therefore, the expected signs of the coefficients are $\mathrm{E}_{1}>0, \mathrm{f}_{2}<0$ either $\mathrm{f}_{3}<0$ or $\mathrm{f}_{3}>0$, and $\mathrm{f}_{4}>0$.

The results of the estimation of Equation (13), with the addition of seasonal dummy variables, on a quarterly basis for the period 1975:2 to 1984:2 are presented in Table 1 . The coefficients on the change in reserves and the growth of GDP are statistically significant; the fiscal deficit appears to be insignificant, while the race of inflation has the wrong sign. The sterilization coefficient equals -1.24 , which is not statistically different from -1.0 . The results suggest that the authorities tried co insulate the monetary base from the effects of reserve fluctuations, while accommodating movements in money demand due to seasonal factors and growth in real output. The insignificance of the fiscal deficit and the incorrect sign of the coefficient on inflation are very counterintuitive. Inflation has been a key concern of monetary policy throughout the period, and in the early 1980 s a large portion of the public sector deficit was financed by the Banco de la Republica.

\section{The crawling peg and exchange rate expectations}

Under the crawling peg, the authorities depreciate the peso at Erequent intervals without preannouncing any schedule of exchange rate adjustments. The exchange value of the peso appears to have reacted in part to the performance of the overall balance of payments. The quarterly rate of depreciation of the peso in relation to the U.S. dollar decilined steadily between 1975 and early 1977, the period of the coffee boom due to the Brazilian frost (Chart 3). The rate of crawl then fluctuated somewhat until 1980 , but overall it was at a slightly faster pace chan that during the period 1975-77. After steady depreciation of about 3 percent quarter between early 1980 and 1 ate 1982 , the authorities stepped lip the rate of depreciation in the fourth quarter of 1982 to about 5-6 percent a quarter in response to the growing balance of payments deficic. This pace was maintained until 1985, when the peso was depreciated by over 50 percent during the course of the year.

To examine the behavior of exchange rate policy, we assume the authorities try to achieve a target level of the real exchange rate, $S$ :

$$
S_{t}=\frac{e_{t} P_{t}^{* *}}{P_{t}}
$$

The preferred value of the real exchange rate depends on the adequacy of international reserves and the performance of nontraditional exports. 
Table 1. Colombia: Banco de la Republica Domestic Credit Policy $\underline{1}$

\begin{tabular}{|c|c|c|c|c|c|c|c|c|c|c|c|}
\hline Constant & DI & 02 & D3 & $\overline{\mathrm{e}} D R_{t}$ & $\hat{P}_{t}$ & $\hat{Y}_{t}$ & $D_{t}$ & $\overline{\mathrm{R}}_{2}$ & $\overline{\mathrm{p}}$ & $F$ & $\begin{array}{c}\text { Time } \\
\text { Period }\end{array}$ \\
\hline $\begin{array}{c}1.21 \\
(0.11)\end{array}$ & $\begin{array}{c}-16.00 \\
(1.03)\end{array}$ & $\begin{array}{r}-16.33 \\
(7.82)\end{array}$ & $\begin{array}{c}-16.18 \\
(1.1 .70)\end{array}$ & $\begin{array}{l}-1.24 \\
(5.55)\end{array}$ & $\begin{array}{c}297.50 \\
(1.87)\end{array}$ & $\begin{array}{c}2.36 \\
(2.32)\end{array}$ & $\begin{array}{l}-0.01 \\
(0.28)\end{array}$ & 0.84 & $\begin{array}{l}-0.64 \\
(4.91)\end{array}$ & 28.41 & $\begin{array}{l}1975: 2 \\
1984: 2\end{array}$ \\
\hline
\end{tabular}

T- statistics reported in parentheses.

1/ Estimates were obtained using two stage least squares with the Sargan correction for first order autocorretation. The dependent variable is a measure of domestic monetary policy of the Banco de la Republica, as Jefined in Appendix II. The instruments were the three seasonal dummy variables, the government deficit lagged one and two periods, the change $1 n$ net international reserves lagged one and two periods, domestic inflation lagged one and two periods, the growth in real GDP lagged one and two periods, the real exchange rate lagged one and two periods, the change in domestic credit lagged one and two perlods, the current and lagged U.S. interest rate, and the current and lagged real export price of coffee. 
CHART 3

COLOMBIA

ACTUAL DEPRECIATION

(in percent per quarter)

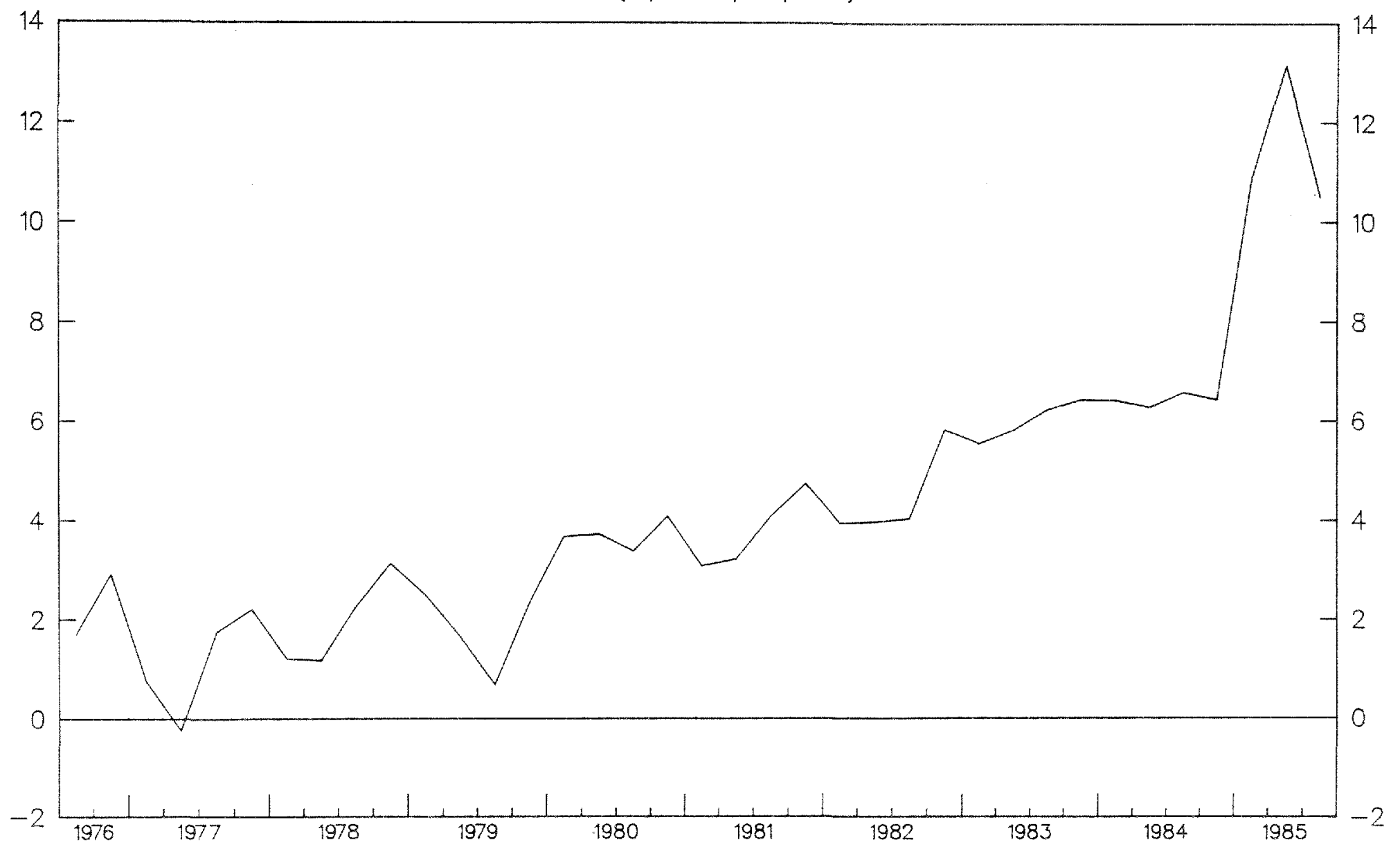


We assume this target is related log linearly to proxies for these objectives:

$$
\ln s_{t}=g_{0}+g_{1} \ln \left(\frac{R}{I M}\right)+g_{t} \ln \left(x_{t}^{N T}\right)+g_{2} \ln \left(P_{c t}\right)
$$

where $I M_{t}$ is merchandise imports in terms of U.S. dollars, $X_{t} N T$ is nontraditional exports, and $P_{c t}$ is the real world price of coffee. As international reserves rise relative to imports, the authorities would allow the real exchange rate to depreciate more slowly, or even appreciate, to avoid an excessive accumulation of incernational reserves. The authorities are also interested in export diversification, and would aim at a more depreciated real exchange rate if nontraditional exports were not growing satisfactorily. We also include the real world price of coffee to capture any possible reaction to fluctuations in the value of coffee exports. A sharp increase in the export price of coffee may result in a policy decision to slow the rate of depreciation. Combining Equations (14) and (15) we solve for the targeted depreciation of the peso:

$$
\dot{e}_{t}=\left(\dot{p}_{t}-\hat{p}_{t}^{f}\right)+g_{1}\left(\frac{\dot{R}_{t}}{I M}\right)+g_{2} \dot{x}_{t}^{N T}+g_{3} \dot{p}_{c t}
$$

According to our hypothesis, we expect $g_{1}<0, g_{2}<0$, and $g_{3}<0$. According to thig rule, the rate of nominal depreciation of the peso equals the difference between domestic and foreign inflation plus any adjustments based on the factors that would warrant a change in the real exchange rate.

Table 2 presents the estimates of the coefficients in Equation (16) for the period 1975:2 to 1985:3. The overall results are poor. Although most coefficients have the expected sign, only the coefficient on the real price of coffee ig statistically significant. Moreover, the low F-statistic indicates that this set of variables explains little of the variation in the actual rate of depreciation. Equation $B$ in this table uses the change in net international reserves in U.S. dollars as a proxy for the adequacy of reserves, and the results are substancially better. In this equation, all coefficients have the expected sign, and both domestic inflation and the change in net international reserves are statistically significant.

Despite the reasonable performance of the second equation there is clear evidence of structural instability over time. We estimated Equation $B$ in Table 2 for the periods 1975:2 to 1979:4 and 1980:1 to 1985:3, and the results are presented in Equations $C$ and $D$ in that table. A Chow test leads to a rejection at the 1 percent level of the null hypothesis of no structural change. A comparison of the coefficients 
Table 2. Colombia: Banco de la Republica Exchange Rate Policy I/

\begin{tabular}{|c|c|c|c|c|c|c|c|c|c|c|}
\hline & $\hat{P}_{t}$ & $\hat{P_{t}}$ & $(\bar{R} / \mathrm{M})_{t}$ & $\hat{R}_{t}$ & $x^{n t}$ & $\hat{P}_{c t}$ & p & $\mathrm{D}-\mathrm{W}$ & $\mathrm{F}$ & Time Period \\
\hline (A) & $\begin{array}{l}0.062 \\
(0.73)\end{array}$ & $\begin{array}{r}-0.0035 \\
(1.23)\end{array}$ & $\begin{array}{r}0.00009 \\
(0.95)\end{array}$ & -- & $\begin{array}{r}0.00004 \\
(0.62)\end{array}$ & $\begin{array}{r}-0.0003 \\
\quad(2.28)\end{array}$ & $\begin{array}{c}1.02 \\
(28.44)\end{array}$ & -- & 1.98 & $1975: 2-1985: 3$ \\
\hline (C) & $\begin{array}{c}0.46 \\
(1.12)\end{array}$ & $\begin{array}{r}-0.012 \\
(1.15)\end{array}$ & -- & $\begin{array}{c}0.0014 \\
(1.92)\end{array}$ & $\begin{array}{r}-0.0004 \\
(0.54)\end{array}$ & $\begin{array}{r}-0.0009 \\
\quad(1.65)\end{array}$ & -- & $2 \cdot 12$ & 3.07 & $1975: 2-1979: 4$ \\
\hline (D) & $\begin{array}{c}1.46 \\
(3.31)\end{array}$ & $\begin{array}{c}-0.014 \\
(1.20)\end{array}$ & -- & $\begin{array}{c}0.0007 \\
(0.42)\end{array}$ & $\begin{array}{l}0.001 \\
(0.82)\end{array}$ & $\begin{array}{r}-0.0005 \\
\quad(0.31)\end{array}$ & -- & 1.59 & 3.02 & $1980:-1985: 3$ \\
\hline
\end{tabular}

T-statistics reported in parentheses.

1/ Estimates for Equation A were obtained using two stage least squares with the Sargan correction for first order auto correlation when necessary. Instruments were current and lagged U.S. inflation, current and lagged percentage changes in the real price of coffee, lagged domestic inflation, lagged percentage change in nontraditional exports, lagged percentage changes in net international reserves, relative to merchandise imports and lagged rates of devaluation. Equations $B, C$ and $D$ were estimated with two stage least squares with no correction for serial correlation. The instruments were the same as in $A$, except the lagged percentage change in net international reserves replaced the reserves relative to imports variable. 
and their t-statistics also reveals clear evidence of a change. For example, the coefficient on domestic inflation is not statistically different from $l$ in the second time period, while it is not statistically different from $O$ in the first period. The estimates of the parameters are very sensitive to changes in the time period and to minor changes in the specification of this model. Thus, these findings cast doubt on the existence of a systematic quanticative rule that explains the rate of crawl and that could serve as a basis for estimating the expected exchange rate. This view is supported by the results of Dickey Fuller tests (Table 3) $1 /$ on the random walk properties of the exchange rate, which imply that the exchange rate followed a random walk during the sample period.

As an alternative, we relied on the information contained in the secondary market price of exchange certificates to develop a proxy for the expected rate of depreciation of the peso. Exchange certificates are U.S. dollar denominated, noninterest bearing bonds issued by the Banco de la Republica to exporters in return for their foreign exchange. The Banco de la Republica regulates the period after which the exporter, or the holder of the certificate, may redeem it for pesos at full face value at the exchange rate on the date of redemption. There is a secondary market for exchange certificates, which allows any investor to hold them for speculative motives.

A risk neutral investor would be willing to buy these certificates if their return equals or exceeds the return to holding pesos. The return to holding an exchange certificate equals:

$$
i_{e c_{t}}=\frac{E\left(e_{t+1}\right)}{P_{e c}}
$$

where $i_{e c}$ is the return on exchange certificates. E( $\left.e_{t+l}\right)$ is the expected Exchange rate of the peso at the end of the holding period, and $P$ ec is the spot price of the certificate in terms of pesos per U.S. doftar in the secondary market. We assume that arbicrage sets this return equal to the return to holding certificates of deposit, or

$$
\left(1+i_{t}\right)=\frac{E\left(e^{e} t+1\right)}{e_{e c}}
$$

1/ Dickey, D. and Fuller W., "Likelihood Ratio Statistics for Autoregressive Time Series with a Unit Root," Econometrica, v. 49, 1981. 
Table 3. Colombia: Random Walk Test of the Exchange Rate, (1977:1 to $1985: 4)$

$$
\begin{aligned}
& e_{t}=0.73+0.88 e_{t-1}+0.07\left({ }^{t}-\frac{T}{2}\right) \\
& (1.86) \quad(8.38) \quad(1.97) \\
& F(2,133)=138.2 \\
& \overline{\mathrm{R}}^{2}=0.89 \\
& \text { Durbin } \mathrm{H}=-0.21 \\
& \mathrm{~T}=\text { number of observations }=36
\end{aligned}
$$

T-statistics reported in parentheses. 
This condition is analogous to uncovered interest arbitrage, except in this case the foreign asset in question pays no interest. From this relationship, we derive the expected race of depreciation:

$$
\frac{E\left(e_{t+1)}^{e}\right.}{e_{t}}-1=\frac{P_{e c t}}{e_{t}}\left(1+i_{t}\right)-1
$$

We recognize that the assumption used to compute this proxy is inconsistent with the assumption of risk aversion that forms the basis of our model, but in the absence of better information on expectations, we believe this measure provides a reasonable estimate of exchange rate expectations.

The resulting time series on the expected rate of depreciation is compared to the actual rate of depreciation in Chart 4. It seems clear that the actual race of crawl would serve as a poor basis for the expected rate of depreciation. According to our estimates, the market began in 1980 to expect a faster depreciation than the actual rate of depreciation and the gap widened in 1982 and 1983 in response to the deteriorating performance of the balance of payments. There appears to have been a sharp loss of confidence in the third quarter of 1983, which was partly reversed by the middle of 1984 . The market seemed to anticipate correctly the substantial devaluation of 1985. 1/

\section{Asset demands}

In chis section, we estimate the demand for net foreign assets and domestic money using the specifications given in the theoretical model, with a few modifications. Because of the capital controls in Colombia, we assume that the stock of net foreign assets adjusts gradually over time to its desired level:

$$
\text { (20) } \frac{e_{\tau} F_{T}}{P_{\tau}}-\frac{e_{\tau-1} F_{\tau-1}}{P_{\tau-1}}=\lambda_{2}\left(\frac{e_{\tau} F_{\tau} *}{P_{\tau}}-\frac{e_{\tau-1} F_{\tau-1}}{P_{\tau-1}}\right)
$$

where $0<\lambda_{2}<1$ and $F^{*}$ is the desired stock of net foreign assers.

1/ This sustained gap between the actual and the expected rate of depreciation raises the question of whether the difference is due to a time varying risk premium or the presence of a "peso problem". Mondino (1987) provides evidence suggesting that the expected depreciation was driven more by the expectation of a sizable devaluation than by a time varying risk premium. 
By substituting Equation (2) into Equation (20), the actual demand for net foreign assets equals:

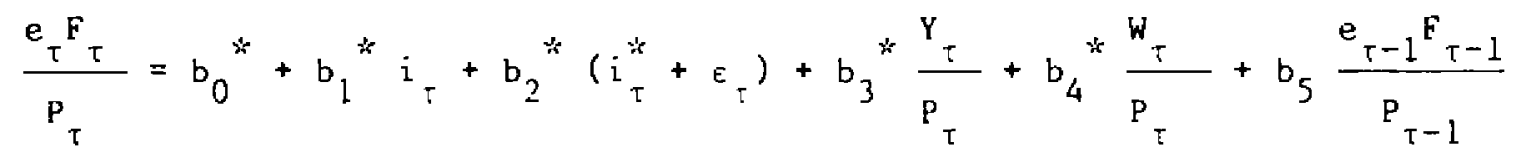

where $b^{*}=\lambda_{2} b_{j}$ for $j=0$ to 4 and $b_{5}=1-\lambda_{2}$. A value of $b_{5}$ close to 1 indicates d low value of $\lambda_{2}$ and a slow speed of adjustment. Slow adjustment also diminishes the immediate response of actual demand to changes in the explanatory variables. We measure the stock of net foreign assets by taking the stock of deposits of Colombian residents in the U.S. banking system and subtracting the deposits in U.S. banks of the Banco de la Republica and the foreign liabilities of the Colombian financial system, excluding the Banco de La Republica. Admittedly, this proxy suffers from a number of shortcomings, but in view of the difficulties with using Colombian balance of payments data or capical flows, there appears to be no better measure.

The estimation of the demand for net foreign assets produced reasonable results (Table 4). This demand is very sensitive to both the domestic and the foreign rate of return. Because the coefficient on the domestic interest rate in Equation $A$ is statistically insignificant and larger than the coefficient on the foreign rate of recurn, Equation $B$ tests the null hypothesis that the response to each rate of return is equal but of the opposite sign, and an E-test fails to reject this hypothesis. 1/ Real wealth appears to be statistically insignificant, probably because of a high degree of colinearity with the lagged stock of net foreign assets. The value ot $b_{5}$ in both equations is between 0.8 and 0.9 , indicating a slow rate of adjustment. After a change in one of the explanatory variables, roughly 50 percent of the desired adjustment is completed after one year and 75 percent after two years.

The demand for domestic money is also assumed to follow a partial adjustment process:

$$
\frac{M_{\tau}}{P_{\tau}}-\frac{M_{\tau-1}}{P_{\tau}-1}=x_{3}\left(\frac{M_{\tau}}{P_{\tau}}-\frac{M_{\tau}-1}{P_{\tau}-1}\right)
$$

1/ The value of the F-statistic is 0.90 , which is less than the critical value of $F(1,31)=7.56$ at the 1 percent level of significance. 
CHART 4

COLOMBIA

ACTIJAL YERSUS EYPECTED RATE OF DEPRECIATION

(In percent per quarter)

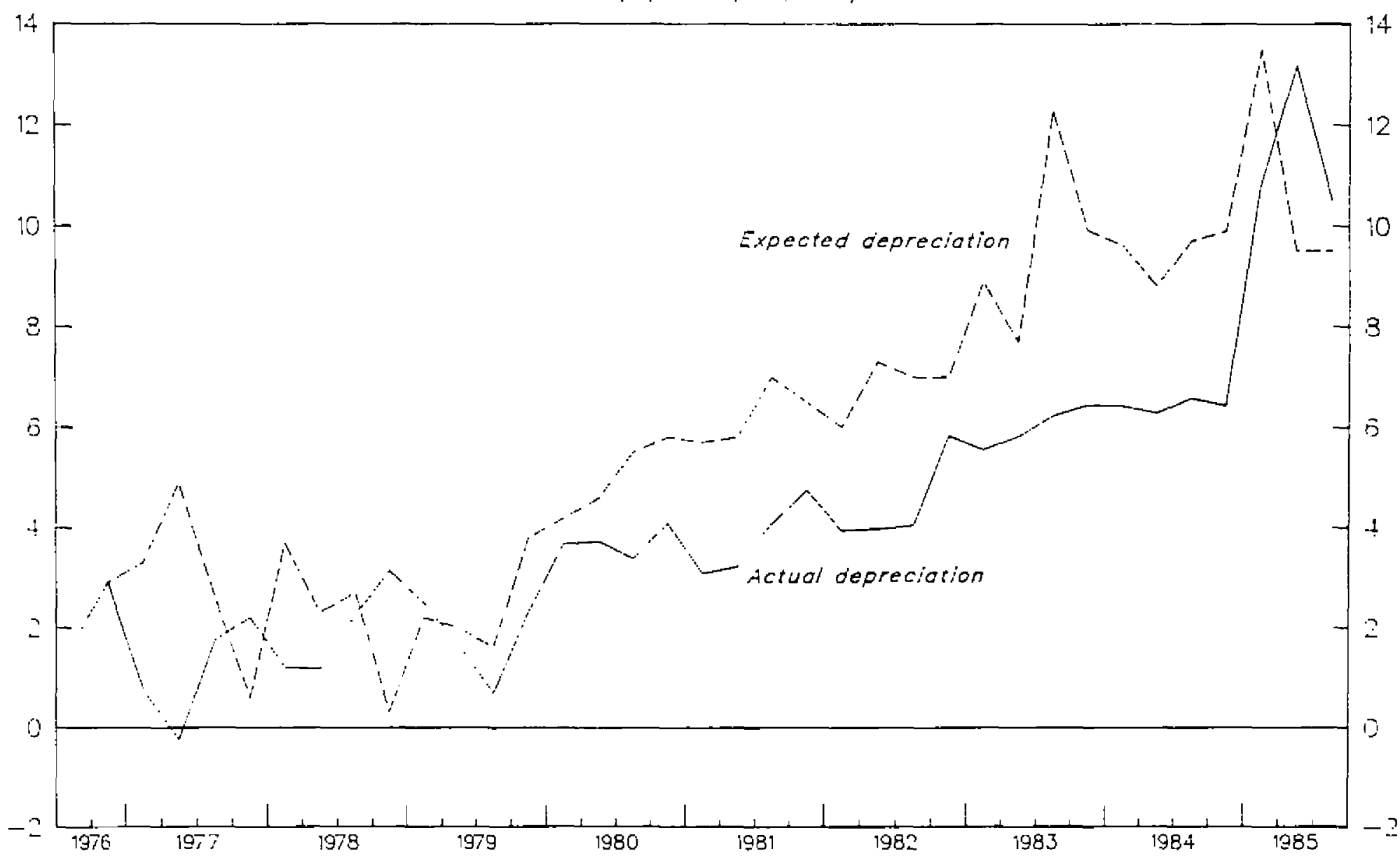


Table 4. Colombia: Real Demand for Net Foreign Assets (1976:4 to 1985:3) If

\begin{tabular}{|c|c|c|c|c|c|c|c|c|c|}
\hline & Constant & $i_{t}$ & $i_{t}+$ & $W_{t} / P_{t}$ & $\frac{e_{t-1} F_{t-1}}{P_{t-1}}$ & $\overline{\mathrm{R}}^{2}$ & $\begin{array}{c}\text { Durbin } \\
\mathrm{H}\end{array}$ & $F$ & SSR \\
\hline (A) & $\begin{array}{l}-4.92 \\
(0.25)\end{array}$ & $\begin{array}{c}-344.7 \\
(1.24)\end{array}$ & $\begin{array}{r}233.1 \\
(2.59)\end{array}$ & $\begin{array}{c}0.08 \\
(0.67)\end{array}$ & $\begin{array}{c}0.85 \\
(8.02)\end{array}$ & 0.91 & -0.22 & 86.82 & 18.18 \\
\hline
\end{tabular}

T-statistics reported in parenthesos.

L/ Estimates were obtained by two stage least squares. Instruments were the three seasonal dumm variathes, the lagged domestic interest rate, the current and lagged l.s. interest rate, the lagged expected rate of depreciation, the lagged change in domestic credit, the lagged real public sector deficit, the lagged change in net international reserves, the current real price of coffee, the lagged real money supply, and lagged real wealth. 
where $0 \leq \lambda_{3} \leq 1$. Substituting Equation (1) into Equation (22) yields:

$$
\frac{M_{\tau}}{P_{\tau}}=a_{0}{ }^{*}+a_{1}{ }^{*} i_{\tau}+a_{2}{ }^{*}\left(i_{\tau}^{*}+\varepsilon_{\tau}\right)+a_{3}{ }^{*} \frac{Y_{\tau}}{P_{\tau}}+a_{4}{ }^{*} \frac{W_{\tau}}{P_{T}}+a_{5} \frac{{ }^{M}-1}{P_{\tau-1}}
$$
where $a^{+}=\lambda_{3}{ }^{2}$ for $j=0$ to 4 and $a_{5}=1-\lambda_{3}$. We also incorporate
dummy variables to capture the seasonal shifts in money demand.

Table 5 contains the estimation of the real demand for money. The estimates presented are based on ordinary least squares. $1 /$ The seasonal variation in real money demand is statistically significant, with a sharp increase in demand in the fourth quarter. Both the domestic interest rate and real GDP are important explanatory variables. In Equation $A$, the short run elasticity of money demand with respect to the domestic interest rate is -0.17 , while the short-run income elasticity equals 0.52. In Equation $\mathrm{A}, \mathrm{a}_{5}=0.34$ and is statistically significant. For this level of $a_{5}$, 90 percent of the desired adjustment occurs after two quarters, and the process is virtually complete after one year. As shown by Equation $B$, the empirical results are still quite good without the lagged dependent variable. The estimate of $a_{2} * i n$ Equation $B$ implies that the short run elasticity of money demand with respect to the foreign rate of return is -0.05 , and is statistically significant. The foreign rate of return may have some significant effect on money demand in Colombia. Given the thinness of secondary markets for public debt instruments in Colombia, these assets are much less liquid than narrow money, and thus substitution should occur between both types of domestic assets and net foreign assets. The results of these equations provide some evidence for this hypothesis.

\section{The degree of capital mobility}

The structural parameters of the asset demand equations form the basis for estimating the degree of capital mobility and the independence of monetary policy. In this section, the offset coefficient is calculated for both an open market operation and a helicopter drop, and the results are reported in Table 6 , using the parameter estimates from Equation $B$ in Table 4 and Equation $A$ in Table 5. In the short run, an open market purchase of bonds by the Banco de la Republica of Col\$1 billion would generace a capital outflow of only Col\$390 million,

1/ Hausman's procedure was used to test the null hypothesis of exogeinity and this hypothesis was not rejected. Because ordinary least squares is more efficient than simultaneous estimators, it was decided to rely on this estimation technique. 
Table 5. Colombia: Real Demand for Ml (1975:2 to 1984:2) I/

\begin{tabular}{|c|c|c|c|c|c|c|c|c|c|c|c|c|}
\hline & Constant & Dl & $\mathrm{D} 2$ & D3 & $1_{t}$ & $i_{t}^{*}+e_{t}$ & $\frac{Y_{t}}{P_{t}}$ & $\frac{M_{t-1}}{P_{t \cdots 1}}$ & $\overline{\mathrm{R}}^{2}$ & $\sim$ & F & $D-W$ \\
\hline (A) & $\begin{array}{c}72.2 \\
(6.67)\end{array}$ & $\begin{array}{l}-15.3 \\
(2.69)\end{array}$ & $\begin{array}{l}-14.0 \\
(4.66)\end{array}$ & $\begin{array}{l}-18.8 \\
(5.42)\end{array}$ & $\begin{array}{r}-437.5 \\
(3.72)\end{array}$ & $\begin{array}{l}-81.4 \\
(1.55)\end{array}$ & $\begin{array}{c}1.69 \\
(3.79)\end{array}$ & $\begin{array}{c}0.34 \\
(2.49)\end{array}$ & 0.85 & $\begin{array}{l}-0.38 \\
(2.05)\end{array}$ & 47.68 & - \\
\hline (E) & $\begin{array}{c}89.2 \\
(7.30)\end{array}$ & $\begin{array}{c}-3.2 \\
(1.24)\end{array}$ & $\begin{array}{c}-9.6 \\
(3.79)\end{array}$ & $\begin{array}{l}-14.0 \\
(5.43)\end{array}$ & $\begin{array}{r}-591.9 \\
(3.91)\end{array}$ & $\begin{array}{c}-140.1 \\
(2.58)\end{array}$ & $\begin{array}{c}2.67 \\
(10.21)\end{array}$ & - & 0.85 & - & 35.64 & 2.24 \\
\hline
\end{tabular}

T-statistics reported in parentheses.

1/ Estimates were obtained by ordinary least squares. 
Table 6. Colombia: The Degree of Capttal Mobility

A. The offset coefficient I/

Open market operation

$-0.39$

$-0.72$

Helicopter drop

$-0.46$

$-0.92$

B. Response of the domestic interest

rate to the foreign rate of return

0.28

0.67

1/ Est Imates obtained using a value of 1.48 for the money multiplier, its value in the fourth quarter of 1976, the first observation in the equation for the demand for net foreign assets. 
indicating a significant degree of control over the domestic supply of Ml. An expansion of domestic credit of the same amount that increased private wealth would result in a slightly larger capital outflow of about col $\$ 460 \mathrm{million}$. There is little difference in the short run between an open market operation and a helicopter drop because the wealth effect on the demand for net foreign assets is not significant. Once both asset stocks adjust to their desired levels, the control over the money supply is diminished substancially. An open market operation appears to still have some long-run impact, but a helicopter drop would ultimately lead to an offsetting flow of capital. Nonetheless, the slow speed of adjustment of the demand for net foreign assets suggests that the reduction in monetary control would take place gradually.

The short-term control over the stock of narrow money explains part of the apparent independence of colombian interest rates from variation in the foreign interest rate and the expected cate of jepreciation. According to our empirical model, a 10 percent increase in the foreign rate of return would translate into approximately a 3 percent increase in the domestic interest rate within one quarter, and once the demand Eor net foreign assets has adjusted to its desired level, the model predicts that the domestic interest rate will have risen by about 7 percent. As illustrated in Chart 2, however, the domestic interest rate has stayed very close to 35 percent in the period 1980-85, while the foreign rate of recurn rose significantly. Thus, it seems clear that the factors incorporated in this model, i.e., risk premia and capital controls, fail to explain much of the stabilicy of domestic interest rates.

\section{Concluding Remarts}

In this paper, we have estimated a small struccural model of Colombian financial markets to examine the degree of independence of the money stock and the level of domestic interest rates from external. factors. The results of this paper are subject to several limitations. The model ignores the impact of monetary and exchange rate policy on the rate of inflation and the current account of the balance of payments. It is likely that the estimated degree of independence of monetary policy would be less in a model that took these factors into account. Moreover, the measure used for the stock of private net foreign assets may not be a good approximation of the true variable.

According to the results of the model, the authorities possess some control over the money supply in the short run. Nonetheless, once the stock of net foreign assets has adjusted to its desired level, the degree of monetary control is substantially less for open market operations, and helicopter drops are almost fully offset through the private capital account. The stock of net foreign assets adjusts relatively slowly, with 50 percent of the adjustment occurring after one year and 75 percent after two years, and thus the loss of monetary control takes place gradually. The difference between the short-run and the long-run 
offset coefficients suggests that much of the short-term monetary control comes from the presence of capital controls. Nonetheless, the degree of substitutability between domestic and foreign assets appears to be low, which could provide a limited degree of monetary control for open market operations.

The results of the estmation of this model also suggest certain implications for Colombia's use of a crawling peg exchange rate policy. The foreign rate of return, which includes the expected rate of depreciation of the peso, has a sizable and statistically significant impact on the demand for net foreign assets, and thus an acceleration of the rate of crawl could result in a capital outflow, if private investors were not expecting such a shift in policy. Nonetheless, it would appear that the 50 percent nominal depreciation of the peso against the U.S. dollar in 1985 did not produce an outflow of capital. According to the proxy developed in this paper, the expected rate of depreciation rose sharply in 1983-84 in response to the continued loss of official foreign exchange, generating a significant increase in private net foreign asset holdings in those years. Because the 1985 depreciation seemed to be close to what the market had expected, private net foreign assets appeared to stop increasing in 1985. The model also implies that the expectation of depreciation in 1983-84 should have led to at least some increase in domestic interest rates, which should have then remained stable in 1985. The actual relationship between domestic and foreign rates of return is clearly much weaker than can be explained by the model.

The results of this paper raise areas for further research. To improve the understanding of the behavior of domestic interest rates, it would be useful to study factors on the supply side of credit markets in Colombia, such as a low degree of competition in the banking system, that may influence the variability of domestic interest rates. In addition, it would be important to look at the determinants of the expected rate of depreciation to learn more about the impact of policy on expectations. 


\section{Data Source}

I .

\section{Variable}

Narrow money

Colombian CPI

Colombian interest rate

(rate on 90-day certifi-

cates of deposit)

Exchange rate

Real GDP

U.S. interest rate (90-day

treasury bills)

Net international reserves

Deposits of Colombian residents in U.S. banks

\section{Deposits of Banco de la} Republica in U.S. banks

Short term foreign liabilities of Colombian commercial banks and $f$ inancial corporations

Money multiplier

Fiscal deficit

Nontraditional exports

Merchandise imports

World price of coffee

Foreign prices (US CPI)
Symbol

M

$\mathrm{P}$

i

e

y

$i^{*}$

R

- .

... Revista

$9 \quad$ Revista

D IFS, line 80 (Central Govermment)

$x^{n t} \quad$ IFS, line 70 minus $l$ ine $70 e$

$M \quad$ IFS, 1 ine $71 \mathrm{v}$

$\mathrm{P}_{\mathrm{C}} \quad \underline{\mathrm{IFS}}$

p IFS, line 64 


\section{Derivation of the Monetary Policy Measures}

The measure of domestic monetary policy used in this study equals the change in the net domestic credit of the Banco de la Republica adjusted for two factors: (1) the valuation changes in net international reserves due to the depreciation of the peso; and (2) changes in the average reserve ratio, which have been frequent in Colombia. The peso value of net international reserves rises as the peso depreciates relative to the U.S. dollar, and the authorities consciously decide whether to monetize thege gains. Hence the change in net international reserves is valued at the average exchange rate in the period, and the valuation effect is included as part of the change in net domestic credit.

Reserve requirements were raised significantly in the latter half of the 1970s and then reduced in the early 1980s, and the measure of domestic credit policy should incorporate these effects. The stock of narrow money equals:

$$
\text { (1) } M_{\tau}^{S}=M_{\tau}
$$

when $r$ is the average reserve ratio on demand deposits. The change in the money stock equals:

$$
\text { (2) } M_{\tau}^{s}-M_{\tau-1}^{s}=\frac{1}{r_{\tau-1}} \quad\left(M B_{\tau-1}-M B_{\tau-1}\right)+\frac{\left(r_{\tau-1}-r_{\tau}\right)}{r_{\tau-1}} \quad M_{\tau}
$$

According to this expression, the change in the stock of narrow money consists of the growth in the monetary base and the change in the average reserve ratio. To treat adjustments in the average reserve ratio as part of domestic credit policy, we define domestic monetary policy as:

$$
\text { (3) } \Delta M_{\tau}=\frac{r_{O}}{r_{\tau-1}} \Delta D C_{\tau}+\frac{r_{\tau-1}-r_{\tau}}{r_{\tau-1}} \quad M B_{\tau}
$$

where $r_{0}$ is the average reserve ratio in the base period. Multiplying by $r_{0}$ converts this measure of monetary policy into the change in net domestic credit needed to support the observed change in the monetary base if the average reserve ratio had stayed constant throughout the period. 


\section{Bibliography}

1. Argy, V. and P. Kouri, "Sterilization Policies and the Volatility in International Reserves", in Aliber, R. ed. National Monetary Policies and the International Financial system, (University of Chicago Press: Chicago), 1974.

2. Carrizosa, M. and G. Botero, "Trimestializacion del Producto Interno Bruto en Colombia," Coyuntura Economica, Vol XIV, No. 4, December 1984 .

3. Conolly, M. and J. da Silveira, "Exchange-Market Pressure in Postwar Brazil: As application of the Girton-Roper Monetary Model," American Economic Review, Vol. 69, 1979.

4. Cumby, R. and M. Obstfeld, "Capital Mobility and the Scope for Sterilization: Mexico in the 1970s", in Aspe Armella, P. et al eds. Financial Policies and the World Capital Market, (University of Chicago Press: Chicago), 1983.

5. Dickey, D, and W. Fuller, "Likelihood Ratio Statistics for Autoregression Time Series wich a Unit Root," Econometrica, Vol. 49, 1981.

6. Edwards, S., "Money, the Rate of Devaluation, and Interest Rates in a Semiopen Economy: Colombia, 1968-82", Journal of Money, Credit, and Banking, Vol, 17, 1985.

7. Edwards, S. and M. Khan, "Interest Rate Determination in Developing Countries: A Conceptual Framework", International Monetary Fund Staff Papers, Vol. 32, 1985.

8. Fernandez, J. and R. Candelo, "Politica Monetaria y Movilidad de Capitales en Colombia", Ensayos Sobre Politica Economica, 1983.

9. Herring, R. and R. Marston, National Monetary Policies and International Financial Markets. (North-Holland: Amsterdam), 1977.

10. Kamas, L., "External Disturbances and the Independence of Monetary Policy Under the Crawling Peg in Colombia, "Journal of International Economics, Vol. 19, 1985.

11. Kamas, L., "The Balance of Payments offset to Monetary Policy: Monetarist, Portfolio Balance, and Keynesian Estimates for Mexico and Venezuela", Journal of Money, Credit, and Banking, Vol. $18,1986$.

12. Kouri, P. and M. Porter, "International Capital Flows and Portfolio Equilibrium, "Journal of Political Economy, Vol. 82, 1974. 
13. Mondino, G. "Efficient Forward Exchange Markets in Colombia? Risk Premiums, Peso Problems, or Irrationality," Yale University, processed, 1987.

14. Montes G. and R. Candelo, "El Enfoque de la Balanza de Pagos: E1 Caso de Colombia, 1968-1980," Revista de Planeación y Desarro11o, May-August, 1982.

15. Obstfeld, M. "Can We Sterilize? Theory and Evidence", American Economic Review Papers and Proceedings, Vol. 72, 1982.

16. Porter, M., "Capital Flows and the Offset to Monetary Policy: The German Experience, "International Monetary Fund Staff papers, Vol. 19, 1972 . 